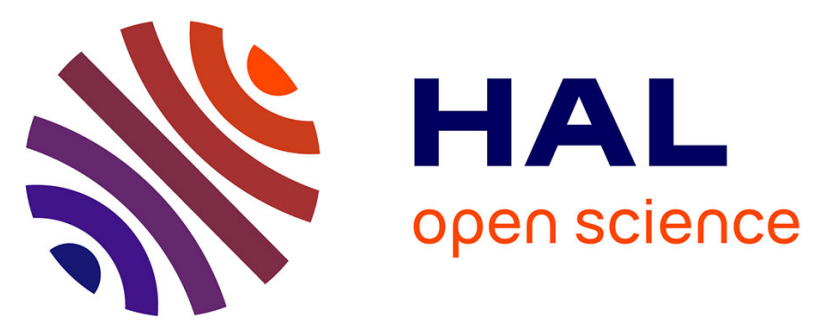

\title{
Greater diversity of HIV DNA variants in the rectum compared to variants in the blood in patients without HAART
}

Véronique Avettand-Fènoël, Laurent Hocqueloux, Michaela Muller-Trutwin, Thierry Prazuck, Adeline Mélard, Marie-Laure Chaix, Eric Agoute, Christophe Michau, Christine Rouzioux

\section{To cite this version:}

Véronique Avettand-Fènoël, Laurent Hocqueloux, Michaela Muller-Trutwin, Thierry Prazuck, Adeline Mélard, et al.. Greater diversity of HIV DNA variants in the rectum compared to variants in the blood in patients without HAART. Journal of Medical Virology, 2011, 83 (9), pp.1499. 10.1002/jmv.22132 . hal-00657572

\section{HAL Id: hal-00657572 https://hal.science/hal-00657572}

Submitted on 7 Jan 2012

HAL is a multi-disciplinary open access archive for the deposit and dissemination of scientific research documents, whether they are published or not. The documents may come from teaching and research institutions in France or abroad, or from public or private research centers.
L'archive ouverte pluridisciplinaire HAL, est destinée au dépôt et à la diffusion de documents scientifiques de niveau recherche, publiés ou non, émanant des établissements d'enseignement et de recherche français ou étrangers, des laboratoires publics ou privés. 


\section{Greater diversity of HIV DNA variants in the rectum compared to variants in the blood in patients without HAART}

\begin{tabular}{|c|c|}
\hline Journal: & Journal of Medical Virology \\
\hline Manuscript ID: & JMV-10-2182.R2 \\
\hline Wiley - Manuscript type: & Research Article \\
\hline $\begin{array}{r}\text { Date Submitted by the } \\
\text { Author: }\end{array}$ & 08-Apr-2011 \\
\hline Complete List of Authors: & $\begin{array}{l}\text { Avettand-Fènoël, Véronique; Hôpital Necker, Laboratoire de } \\
\text { Virologie } \\
\text { Hocqueloux, Laurent } \\
\text { Muller-trutwin, Michaela } \\
\text { Prazuck, Thierry } \\
\text { Mélard, Adeline } \\
\text { Chaix, Marie-Laure; Necker Hospital } \\
\text { Agoute, Eric } \\
\text { Michau, Christophe } \\
\text { Rouzioux, Christine }\end{array}$ \\
\hline Keywords: & $\begin{array}{l}\text { HIV reservoir, gut-associated lymphoid tissue, rectum, phylogeny, } \\
\text { diversity }\end{array}$ \\
\hline
\end{tabular}

\section{SCHOLARONE ${ }^{\text {M }}$ Manuscripts}


Table 1. Virologic, immunologic and clinical characteristics of patients

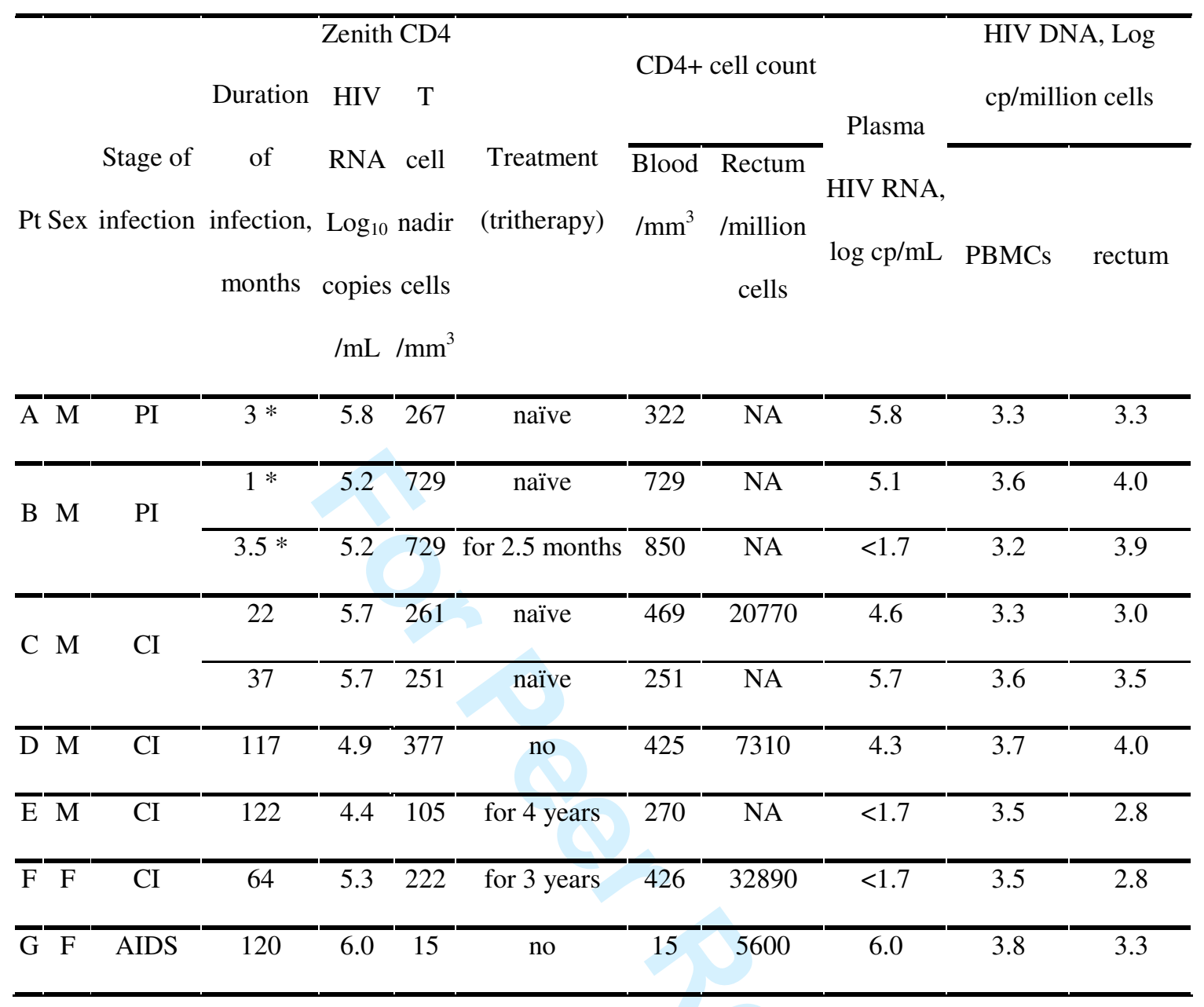

M: male, F: female, PI: primary infection, CI: chronic infection, PBMCs: peripheral blood mononuclear cells, cp: copy

no: no treatment

NA: not available

* after onset of acute retroviral illness 


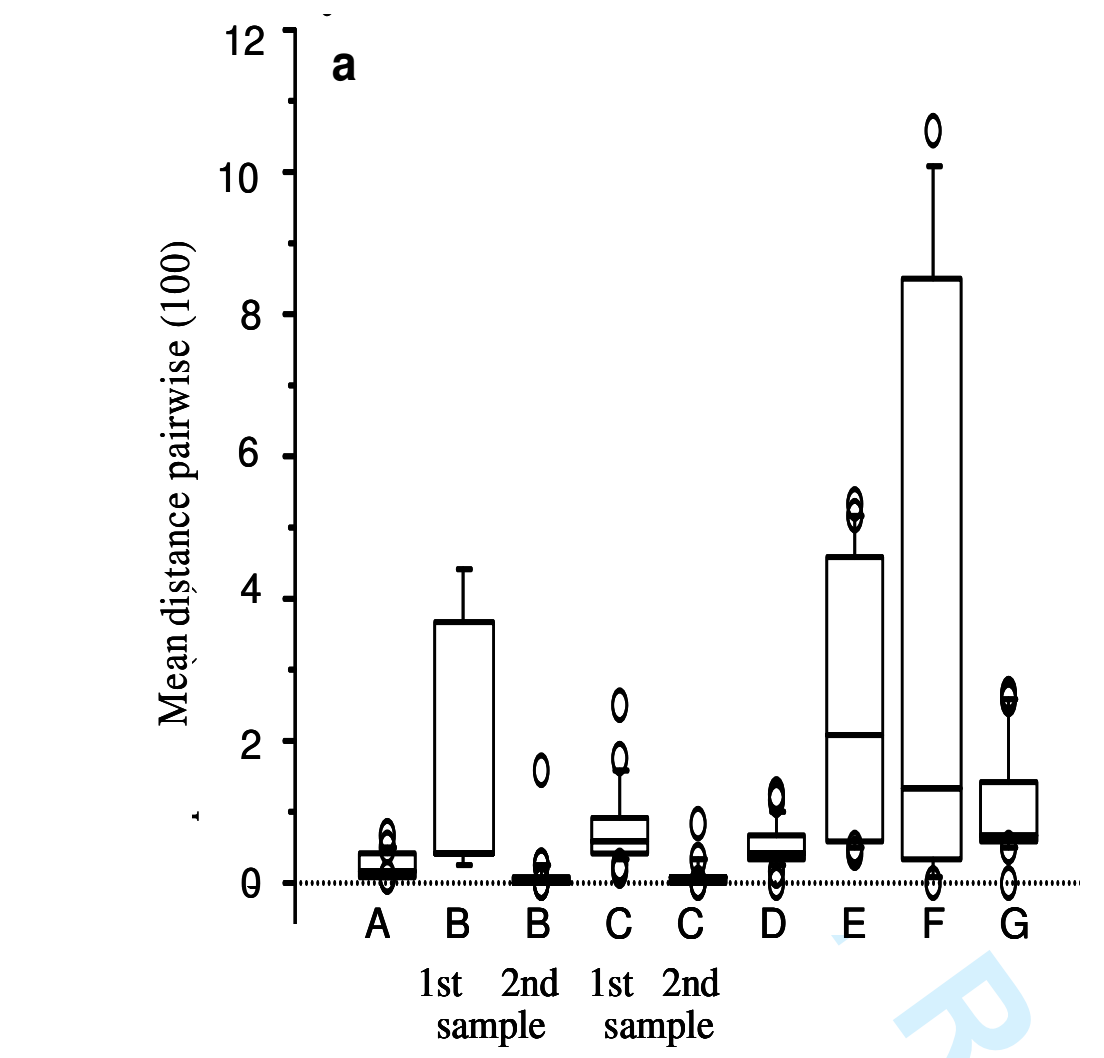

b

Stage of infection PI PI PI CI CI CI CI CI AIDS

HAART

no no yes no no no yes yes no

Difference between the median of distances

within variants from rectum and the median

of distances within variants from PBMC (\%)

$$
\begin{array}{lllllllll}
0.18 & 0.2 & 0 & -0.4 & -1.2 & 0.2 & 0.4 & 0.4 & 0.7
\end{array}
$$

Fig. 1.

Distribution of pairwise distances among rectal HIV-DNA variants (Fig. 1a) and PBMC HIV-DNA variants (Fig. 1b). These boxplots represent the averages of comparisons of pairwise genetic distances from each clone derived from rectal HIV-DNA (Fig. 1a) or from PBMC HIV-DNA (Fig. 1b) to every other clone from the same tissue/fluid. Distances were computed by using the Kimura model and are displayed as 100 times the raw distance score. The horizontal lines show the median and the boxes comprise the first to third quartiles of calculated average genetic distances. A, B, C, D, E, F and G 
1

3

4

5

6

7

8

9

10

11

12

13

14

15

16

17

18

19

20

21

22

23

24

25

26

27

28

29

30

31

32

33

34

35

36

37

38

39

40

41

42

43

44

45

46

47

48

49

50

51

52

53

54

55

56

57

58

59

60

concern viral clones from patient A, B, C, D, E, F and G, respectively. Significant differences

between pairwise rectum HIV-DNA distances and pairwise PBMC HIV-DNA distances were found

for each patient ( $<<0.01$, Mann-Whitney test), except for patients under treatment $\left(B: 2^{\text {nd }}\right.$ set of samples, E and F).

PI: primary infection, CI: chronic infection

Patients A, B ( $1^{\text {st }}$ sample), C are naïve to HAART; Patients D and $G$ had received HAART but, at the time of sample collection, were not receiving treatment. 


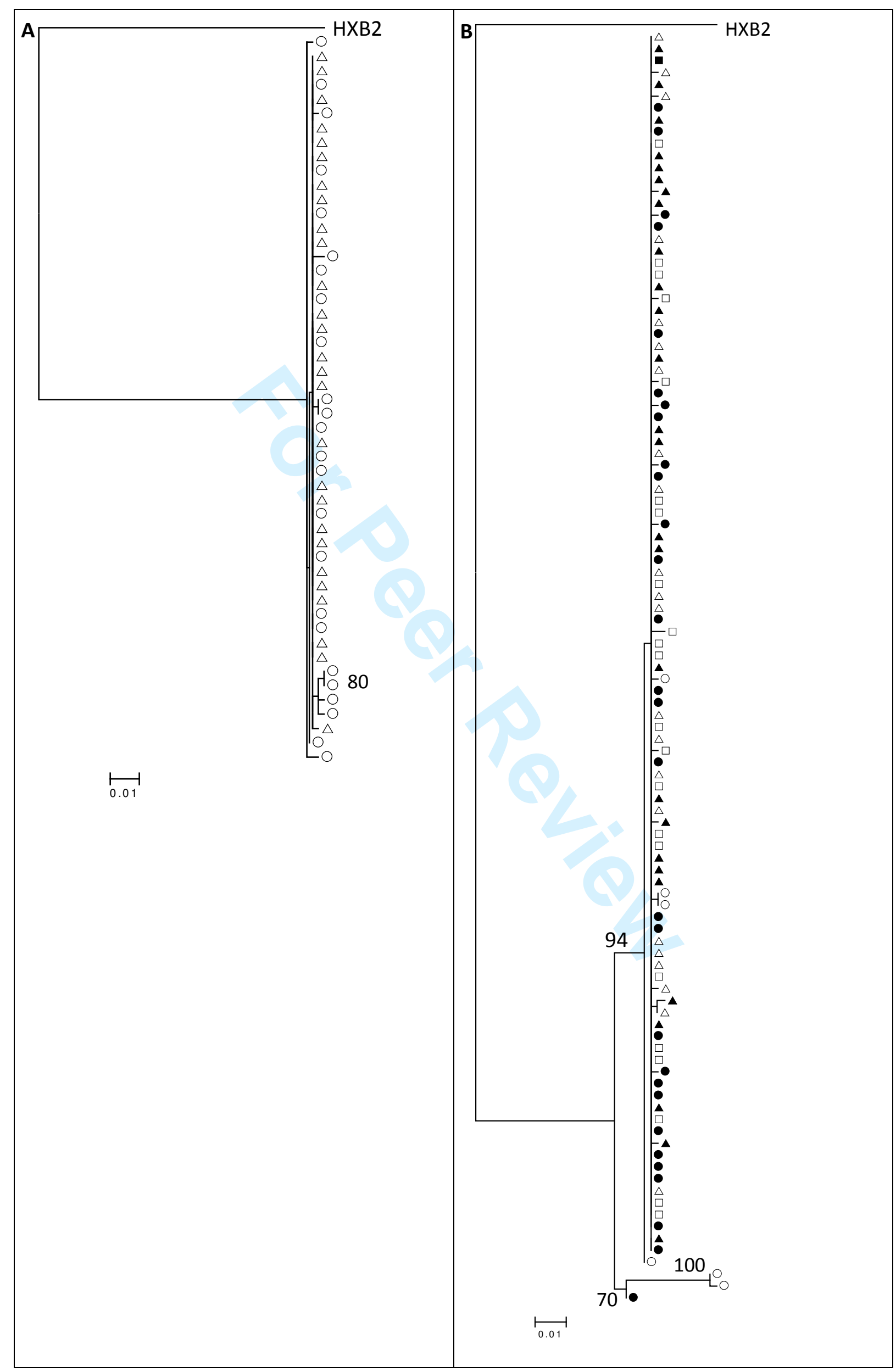

John Wiley \& Sons 


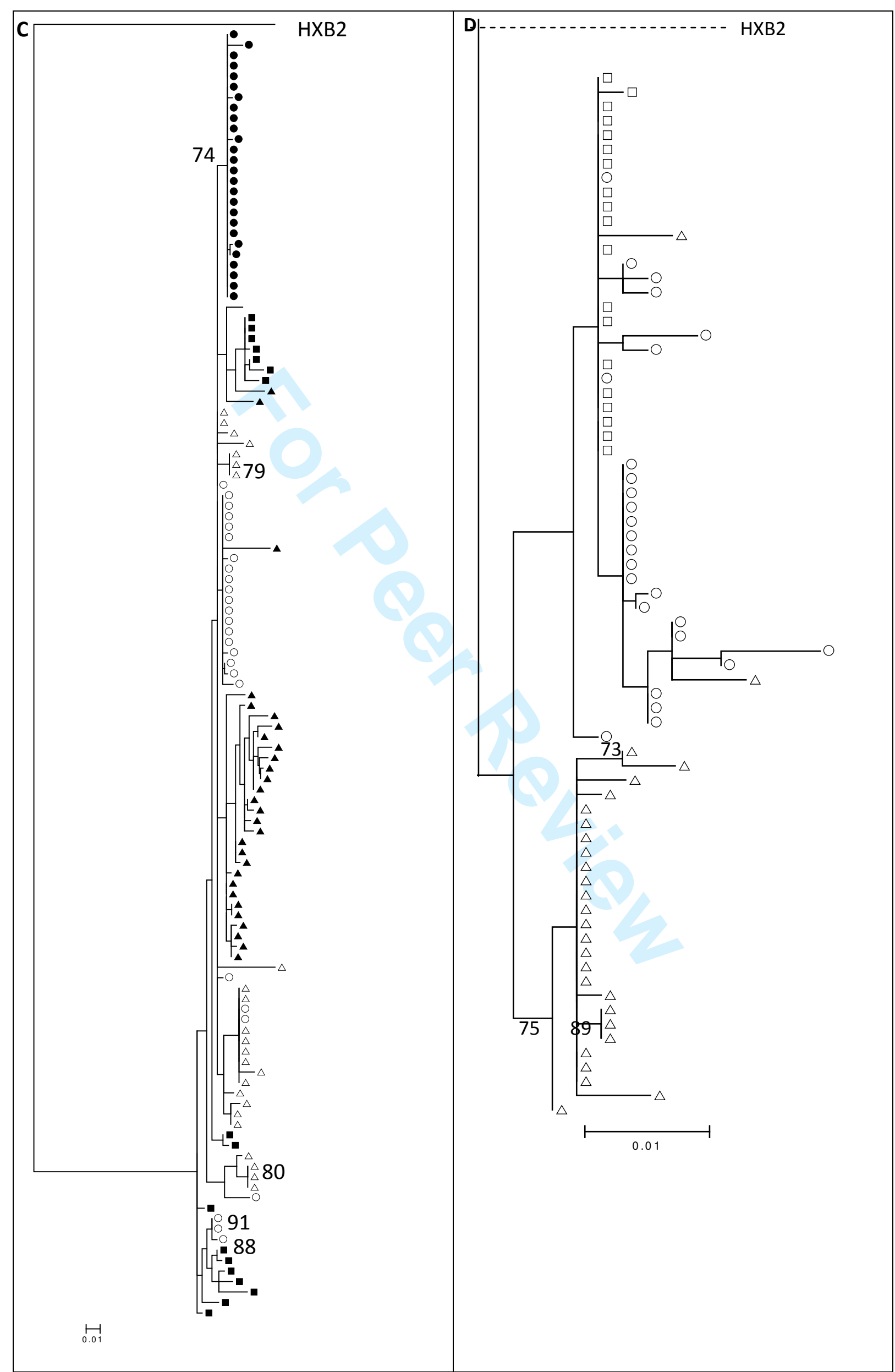




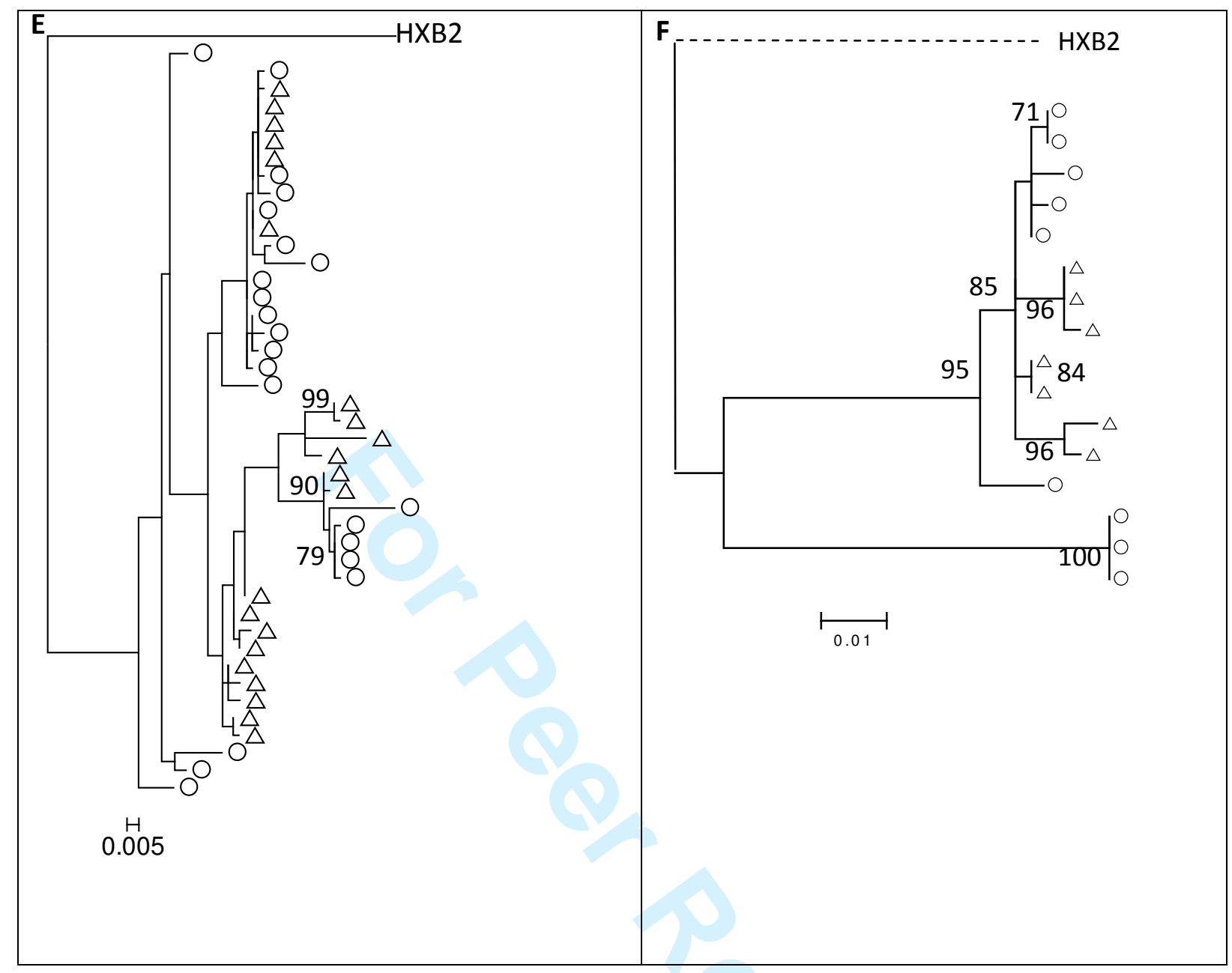




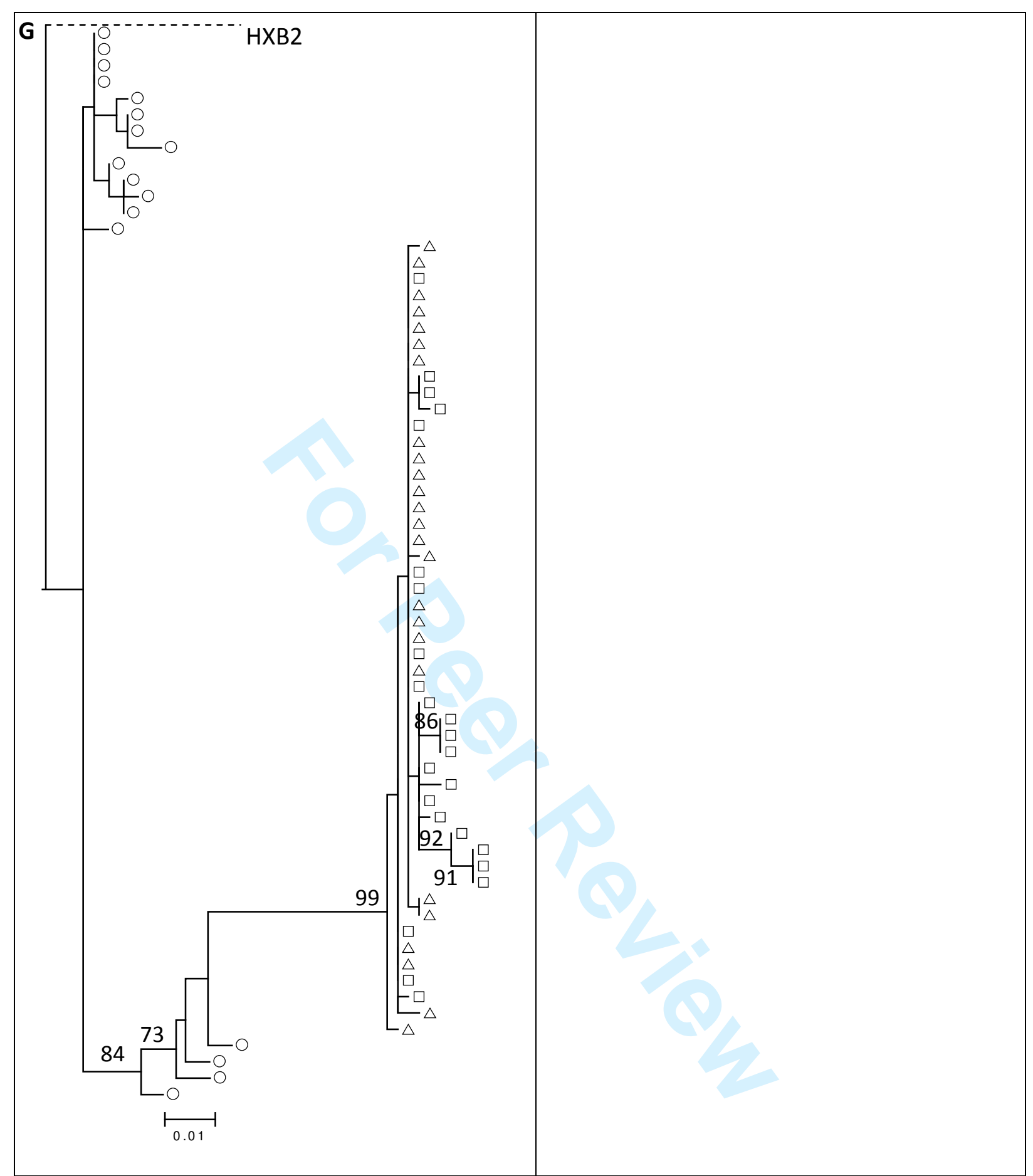

Fig. 2. Phylogenetic relationship of viral clones derived from the blood and rectum (maximum-

likelihood trees, using FR-HXB2 as root). The numbers near the nodes indicate the percentage of bootstrap replicates (1000). Samples at inclusion: rectal HIV-DNA (open circle), blood HIV-DNA (open triangle), blood HIV-RNA (open square); second set of samples for two patients: rectal HIVDNA (full circle), blood HIV-DNA (full triangle), blood HIV-RNA (full square). A, B, C, D, E, F and

G illustrate viral clones from patient A, B, C, D, E, F and G, respectively. All the clusters identified with the maximum-likelihood approach were confirmed using a neighbor-joining analysis. 


\section{Greater diversity of HIV DNA variants in the rectum compared to variants in the blood}

2 in patients without HAART

3

4 Véronique Avettand-Fenoel* ${ }^{1,2}$, Laurent Hocqueloux ${ }^{3}$, Michaela Müller-Trutwin ${ }^{4}$, Thierry

5 Prazuck $^{3}$, Adeline Melard ${ }^{1,2}$, Marie-Laure Chaix ${ }^{1,2}$, Eric Agoute ${ }^{3}$, Christophe Michau ${ }^{5}$,

6 Christine Rouzioux ${ }^{1,2}$

$7{ }^{1}$ AP-HP, Hôpital Necker-Enfants Malades, Laboratoire de Virologie, Paris, 75015, France

$8 \quad{ }^{2}$ Université Paris Descartes, EA3620.

$9{ }^{3}$ CHR d'Orléans - La Source, Orléans, France.

$10{ }^{4}$ Institut Pasteur, Unité de Régulation des Infections rétrovirales, Paris, France.

$11{ }^{5}$ CHR Saint-Nazaire, France.

12

13 Running head

14 Rectal HIV reservoir

$15 *$ Corresponding author

16 Véronique Avettand-Fènoël, Laboratoire de Virologie, Hôpital Necker - Enfants Malades,

17149 rue de Sèvres, 75015 Paris. Phone number: 331444949 61,

18 Fax number: 33144494960 veronique.avettand@nck.aphp.fr

22 Abbreviations: HAART: highly active antiretroviral treatment, HIV: human

23 immunodeficiency virus, PBMCs: peripheral blood mononuclear cells 
26 The gut-associated lymphoid tissue represents the largest reservoir of HIV-1. Improving

27 knowledge of this reservoir by studying the diversity of viral population is a key step towards

28 understanding the pathogenesis and dynamics of HIV. Obtaining samples is difficult and

29 little information is available on gut viral quasispecies during the course of infection in 30 humans.

31 The aim of the study was to characterize rectal viral strains and their diversity and to

32 investigate the relationships between the rectal tissue reservoir and viral variants in the blood.

33 Phylogenetic analyses were performed on the env sequences for rectal HIV DNA, blood HIV

34 DNA and HIV RNA clones, with maximum likelihood and neighbor-joining methods on

35 seven patients. Genetic diversity was assessed.

36 Higher diversity of HIV DNA clones was noted in the rectum compared to blood in 4 out of 5

37 patients without HAART. Viral diversity was present in the rectum from time of the primary

38 infection. Similar degrees of diversity were observed in the rectum and blood during HAART.

39 Rectal and blood HIV variants were interspersed partially or totally in the seven patients. A

40 certain number of rectal HIV DNA clones were clustered together in six patients.

41 These results suggest that variants in the rectum were more heterogeneous than variants in the

42 blood from patients without HAART, probably because the activated milieu of gut-associated

43 lymphoid tissue may provide an improved environment for viral replication, and indicate

44 exchange of viral populations between blood and rectal tissues, reflecting the dynamics of

45 HIV during course of infection.

46 Key words: HIV reservoir, gut-associated lymphoid tissue, rectum, phylogeny, diversity 


\section{Introduction}

The mucosal-associated lymphoid tissue contains $40-60 \%$ of the body's lymphocytes [CerfBensussan and Guy-Grand, 1991; Mowat and Viney, 1997]. The gut-associated lymphoid tissue represents the largest reservoir of human immunodeficiency virus type 1 (HIV-1) [Brenchley et al., 2004; Chase et al., 2006; Clayton et al., 1997; Veazey et al., 1998; Veazey and Lackner, 2005]. Although HIV-1 replication decreases in gut-associated lymphoid tissue with Highly Active Antiretroviral Treatment (HAART), HIV RNA and replication-competent HIV-1 can be detected in gut-associated lymphoid tissue of patients under successful HAART, thus confirming that the intestinal mucosa can act as a residual HIV reservoir despite HAART [Belmonte et al., 2007; Poles et al., 2006].

Improving knowledge of this intestinal reservoir is a key step towards the understanding of the pathogenesis of HIV and better assessment of the efficacy of treatment. Studying the diversity of the viral population within-, and analyzing the potential differences between blood and the intestine may provide an insight into the dynamics of HIV-1.

Previous studies on HIV quasispecies have described HIV compartmentalization in various tissues and fluids, including the brain, lung, semen and cervicovaginal secretions [Chomont et al., 2007; Delwart et al., 1998; Korber et al., 1994; van't Wout et al., 1998; Wong et al., 1997; Zhu et al., 1996]. Due to the difficulty of obtaining samples, little information is available on gut viral quasispecies during the course of infection in humans. Colon-derived HIV-1 variants were studied from autopsied samples from a patient who died of AIDS, but these variants were not compared to circulating blood variants [Wang et al., 2001]. Based on Nef analysis, Van Marle et al. [2007] showed compartmentalization of the gut HIV reservoir in patients infected chronically prior to HAART. However, results were less clear with reverse transcriptase sequences. Poles et al. [2001] have observed the presence of some HIV RNA variants resistant to non-nucleosidic reverse transcriptase inhibitor in gut-associated 
72 lymphoid tissue and in peripheral blood mononuclear cells (PBMCs) which were different

73 from those observed in the plasma. Evidence of cross-infection between gut-associated

74 lymphoid tissue and PBMCs during HAART has been suggested as a possible mechanism for 75 persistence of HIV [Chun et al., 2008].

In this context, the objective of the study was to characterize rectal viral populations, to compare their diversity to the diversity of blood variants, in patients receiving treatment or not, and to investigate the relationship between viral variants in the rectum and those circulating in PBMCs and in the plasma. This study was based on rectal biopsies because they are the easiest gut biopsies to obtain in humans.

\section{Study design}

Patients and samples

85 Seven patients, enrolled in a study described previously [Avettand-Fenoel et al., 2008], were examined. Two of the patients were at the time of the primary infection within four months of 87 the onset of the acute retroviral illness, four patients were infected chronically and one patient 88 had AIDS (Table 1). Blood samples and four punches of rectum including the lamina propria were collected on the same day. In two patients, a second set of samples was taken several

90 months later (B, C) (Table 1). In total, six sets of samples were collected in patients without 91 HAART (A, B first set of samples, C first set of samples, C second set of samples, D, G) and 92 three during HAART (B second set of samples, E, F) (Table 1). Patients A, B ( $1^{\text {st }}$ sample), C 93 were naïve to HAART; Patients D and G had previously received HAART but were not 94 receiving treatment at the time of sample collection (Table 1). Rectal endoscopic biopsies 95 were undertaken at the same site to avoid potential variations among patients. Rectal tissue 
96 was also collected from the same site for histopathological assessment. The local ethics

97 committee approved the study and patients gave their written informed consent.

$98 \quad$ Nucleic acids extraction

99 RNA was extracted from plasma using the QIAamp RNA Mini Kit (Qiagen, Courtaboeuf,

100 France) and used to synthesize cDNA with the Reverse transcriptase core kit (Eurogentec,

101 Angers, France). Total DNA was extracted from PBMCs using the QIAamp DNA mini kit

102 and from rectal tissues using the QIAamp tissue kit (Qiagen). The extracts of the four rectal

103 biopsies collected on the same day from each patient were pooled.

104 Cloning and sequencing

105 The env regions encoding C2-V5 were amplified using a previously described nested PCR

106 [Delwart et al., 1993]. Viral sequences were amplified using an Expand High Fidelity ${ }^{\text {PLuS }}$

107 PCR system (Roche Diagnostics, Meylan, France). To avoid a PCR-based bias, at least two

108 PCRs from the pooled extracts were performed on each sample. Rectal HIV DNA, blood HIV

109 DNA and blood HIV RNA from each patient, as well as the sequential samples, were

110 amplified on different days to avoid contamination. To prevent any inter-sample

111 contamination, water and one sample from each patient were amplified on one day. Moreover,

112 the different amplifications of the samples from each patient were separated by at least two

113 weeks.

114 Phylogenetic analyses

115 A direct cloning of PCR products was performed as described previously [Briat et al., 2005].

116 Clones were sequenced separately from each PCR amplification. Sequences were analyzed

117 with Sequence Navigator software and aligned with ClustalX software [Thompson et al.,

118 1997]. Gap-stripped sequence alignments were performed for each patient. Distances between

119 pairs of sequences were estimated based on Kimura's two-parametric model of nucleotide

120 substitution (DNAdist module - PHYLIP package, v3.67) [Felsenstein, 2001]. The means of 
121 all comparisons of pairwise genetic distances from each clone derived from rectal HIV DNA,

122 from PBMC HIV DNA or from plasma HIV RNA to every other clone from the same

123 tissue/fluid were calculated for each patient. Maximum-likelihood trees were constructed

124 using the HKY model (PHYML v2.4.4) [Guindon and Gascuel, 2003]. The reliability of the

125 branching orders was confirmed by performing 1,000 bootstrap resamplings. In order to

126 confirm the topology of the resulting trees, the distance matrix was employed for

127 phylogenetic analysis with the neighbor-joining method. Bootstrap values $>70 \%$ were

128 considered significant.

129 Statistical considerations

130 The differences detected between pairwise distances among variants from the rectum, variants

131 from PBMCs and variants from plasma were assessed using Mann-Whitney test.

132

133 Results

134 Seven patients were included: patients A and B were at the time of the primary infection;

135 patients $\mathrm{C}, \mathrm{D}, \mathrm{E}$, and $\mathrm{F}$ at chronic infection, and patient $\mathrm{G}$ with AIDS (Table 1). No

136 confounding condition such as inflammation was observed during histopathological analyses

137 of rectal tissue.

138 Overall, phylogenetic analyses were conducted on 522 sequences from clones derived from

139 nine rectal samples, four plasma samples and nine PBMC samples (six to 30 clones per

140 sample, median: 25) (GenBank accession numbers: GQ859192-GQ859245; GQ904239-

141 GQ904706).

142 The phylogenetic analysis showed that all sequences of rectal clones and of blood clones from

143 each patient clustered together, with no contamination between the samples from different

144 patients (bootstrap=100\%) (data not shown).

145 
146 Pairwise distances within HIV DNA quasispecies in the rectum, within HIV DNA variants in

147 PBMCs and within HIV RNA variants in the plasma were calculated. These seven patients

148 with diverse history of infection had very different levels of genetic diversity, with medians of

149 pairwise distances within HIV DNA quasispecies in the rectum ranging from 0.1 to $2.2 \%$

150 depending on the patient taken into account (Fig.1a), from 0.02 to $1.8 \%$ within HIV DNA

151 quasispecies in the PBMCs (Fig.1b) and from 0.04 to $1.95 \%$ within HIV RNA quasispecies in

152 the plasma (data not shown).

153

154 The genetic diversity within HIV variants in the rectum was then compared to the diversity

155 within HIV variants in the blood for each patient. There was a correlation between the

156 diversity of HIV DNA variants in the gut and the diversity of HIV DNA variants in PBMCs

157 among the 9 pairs of samples $(R=0.66, p=0.05)$. Data were presented $\mathrm{i})$ for patients without

158 HAART, ii) for patients with HAART. i) In four out of five patients without HAART, the

159 diversity among HIV DNA variants in the rectum was significantly greater than among HIV

160 DNA variants in PBMCs $(\mathrm{p}<0.0001)$. Differences between the median distance within

161 variants in the rectum and the median distance within variants in PBMCs are presented in

162 Figure 1 (patients A, B first set of samples, D, G). Surprisingly, this was observed from the

163 primary infection stage (A, B first set of samples). The diversity among HIV DNA variants in

164 the rectum was also significantly greater than among HIV RNA variants in the plasma

$165(\mathrm{p}<0.0001)$. Differences between the medians distances within variants in the rectum and

166 within variants in the plasma were $+0.07 \%,+0.46 \%,+0.31 \%$ for the first set of samples of

167 patient $\mathrm{B}$, patient $\mathrm{D}$ and patient $\mathrm{G}$ respectively.

168 ii) During HAART, the genetic diversity within HIV DNA variants in the rectum and within

169 HIV DNA variants in PBMCs for each patient was not statistically different $(p=0.14 ; p=0.35$

170 and $p=0.56$ for patients B (second set of samples), E and F, respectively) (Fig. 1). It was also 
171 noticeable for patient B that the genetic diversity within HIV DNA quasispecies in the rectum

172 was significantly higher before treatment (median $0.25 \%$ ) than during HAART (median

$1730.12 \%)(\mathrm{p}=0.001)$.

174

175 Another objective was to check whether the HIV variants in the rectum and in the blood were

176 interspersed or separated. Phylogenetic analyses showed that variants in the rectum and in the

177 blood were interspersed partially or totally in all the seven patients (Fig. 2). In patients with 178 sequential samples, most of the variants from the first set and variants in the blood from the

179 second set were interspersed $(\mathrm{B}, \mathrm{C})$, showing the persistence of some archived variants in the 180 body over time (Fig. 2). Nevertheless, clusters grouping at least some variants were observed 181 in the rectum in patients $\mathrm{A}, \mathrm{B}, \mathrm{C}, \mathrm{E}, \mathrm{F}, \mathrm{G}$ (bootstrap values $>70 \%$ ) (Fig. 2). It was also 182 noticeable that all the clusters identified with the maximum likelihood analysis were 183 confirmed using a neighbor-joining approach.

186 Discussion

187 Studies carried out on the viral quasispecies in the different tissues could provide useful 188 information enabling understanding of virus trafficking. Very little is known about the gut-

189 associated lymphoid tissue in patients infected with HIV, due to the small size of samples and 190 the difficulty in obtaining such samples. For the first time, the genetic diversity of HIV DNA

191 in the rectum was compared to the genetic diversity of variants in blood, for well-

192 characterized patients either at the time of the primary infection, or during chronic infection 193 and or with AIDS. The HIV DNA variants include archived viral strains accumulated over 194 time, as well as strains from recent infections; while the HIV RNA variants represent recently 
195 produced viral particles. Despite the low number of patients, statistically significant

196 differences were observed.

197 These data suggest that variants in the rectum were more heterogeneous than variants in the

198 blood in patients without HAART. To our knowledge, this is the first report to document that

199 a viral genetic diversity seems to exist in the rectum from the time of the primary infection.

200 For patient B (first set of data), the greater genetic diversity was mainly linked to two

201 sequences of HIV DNA that clustered together. Unfortunately, other rectal HIV DNA

202 sequences could not be recovered in patient B due to the low number of CD4+ T cells in

203 relation to the small size of the rectal biopsies, and further studies will be necessary to

204 confirm that point. One limitation of this study could be the bias introduced by the strategy of

205 PCR cloning. However a recent publication again discussed this point and concluded that this

206 method of cloning is relevant if an adequate number of PCR templates is analysed [Jordan et

207 al., 2010]. In the present study, the number of PCR templates was high (table 1), therefore the

208 strategy of PCR cloning could be considered with a limited bias. Although the existence of

209 undetected minor variants which could influence the viral diversity in PBMCs and in the

210 rectum cannot be excluded, the results may be explained by the activated milieu of the gut-

211 associated lymphoid tissue which may provide an improved environment for the replication of

212 HIV. In a larger group of patients [Avettand-Fenoel et al., 2008], we quantified the

213 proportion of CD4+ rectal cells by immuno-staining in available biopsies for some patients

214 and calculated the HIV DNA load per million of CD4+ rectal cells. It was noted that the HIV

215 DNA load per million of CD4+ rectal cells was higher systematically than the HIV DNA

216 level per million PBMCs, as described by Chun et al. [2008], Chomont et al. [2009] and Yukl

217 et al. [2010]. The microenvironment in the gut-associated lymphoid tissue can be explained

218 by the differences in the local immune selection pressures, the HIV-specific immune

219 response, the constraints on viral entry and the replication rates due to the availability of 
220 activated target cells. The increased error prone replication would result in greater viral 221 diversity.

222 These data suggest that heterogeneity was not significantly different in the rectum and in the 223 blood during HAART, as described previously [Chun et al., 2008]. This observation suggests 224 that HAART played a role in equalizing the dynamics of HIV in the gut-associated lymphoid 225 tissue and PBMCs, although some clusters persisted.

227 In the cases described, the fact that the HIV variants in the rectum, in PBMCs and in the 228 plasma were interspersed underlines that large exchanges of virus particles and/or infected 229 cells occur between these tissues/fluids, as already shown in patients with HAART [Chun et 230 al., 2008]. This is in line with the positive correlation observed between the HIV DNA levels 231 in the rectum and in PBMCs at different stages [Avettand-Fenoel et al., 2008]. As observed 232 previously with the variants of HIV in faeces [van der Hoek et al., 1998] and in the gut233 associated lymphoid tissue [van Marle et al., 2010], complete, independent evolution of HIV2341 was not observed in the intestinal tissue.

235 Nevertheless, in most cases, at least some clones of HIV DNA in the rectum could be 236 differentiated from variants in the blood, as described recently in the esophagus, the stomach, 237 the duodenum, the colon and the blood with phylogenetic and drug mutation analysis [van 238 Marle et al., 2010]. This suggests the existence of local replication foci which could play a 239 major role in the immunopathogenesis of HIV-1 in the altered mucosa.

241 Finally, these results indicate exchange and trafficking of viral populations between blood and 242 lymphoid rectal tissues. The results also suggest that viruses present in the rectum were more 243 heterogeneous than variants in the blood in patients without HAART. Viral diversity is 244 present in the rectum from the time of the primary infection. Studies on the gut-associated 
245 lymphoid tissue may improve understanding the pathogenesis of HIV, the assessment of

246 treatment efficacy and the development of new therapeutic strategies, particularly those

247 aiming at reducing the reservoir.

248

249

250 Acknowledgments

251 We are particularly indebted to the volunteers who agreed to participate in this project.

252 We thank Hayete Djarech who performed rectal biopsies with Eric Agoute, and we

253 acknowledge the participants of the AC32 "Reservoirs" of the ANRS (Agence Nationale de

254 Recherches sur le SIDA et les hépatites virales) for helpful discussions.

255

256 Funding

257 This work was supported by Paris-Descartes University and promotes by Orleans Hospital.

258

259 The authors have declared no conflict of interest in this publication.

260

261 Ethical approval

262 The local ethics committee (Tours, France) approved the study and patients gave their written

263 informed consent.

264

265

266

267

268

269 


\section{References}

Avettand-Fenoel V, Prazuck T, Hocqueloux L, Melard A, Michau C, Kerdraon R, Agoute E, Rouzioux C. 2008. HIV-DNA in rectal cells is well correlated with HIV-DNA in blood in different groups of patients, including long-term non-progressors. Aids 22:1880-1882.

Belmonte L, Olmos M, Fanin A, Parodi C, Bare P, Concetti H, Perez H, de Bracco MM, Cahn P. 2007. The intestinal mucosa as a reservoir of HIV-1 infection after successful HAART. Aids 21:2106-2108.

Brenchley JM, Schacker TW, Ruff LE, Price DA, Taylor JH, Beilman GJ, Nguyen PL, Khoruts A, Larson M, Haase AT, Douek DC. 2004. CD4+ T cell depletion during all stages of HIV disease occurs predominantly in the gastrointestinal tract. J Exp Med 200:749-759.

Briat A, Dulioust E, Galimand J, Fontaine H, Chaix ML, Letur-Konirsch H, Pol S, Jouannet P, Rouzioux C, Leruez-Ville M. 2005. Hepatitis C virus in the semen of men coinfected with HIV-1: prevalence and origin. Aids 19:1827-1835.

Cerf-Bensussan N, Guy-Grand D. 1991. Intestinal intraepithelial lymphocytes. Gastroenterol Clin North Am 20:549-576.

Chase A, Zhou Y, Siliciano RF. 2006. HIV-1-induced depletion of CD4+ T cells in the gut: mechanism and therapeutic implications. Trends Pharmacol Sci 27:4-7.

Chomont N, Hocini H, Gresenguet G, Brochier C, Bouhlal H, Andreoletti L, Becquart P, Charpentier C, de Dieu Longo J, Si-Mohamed A, Kazatchkine MD, Belec L. 2007. Early archives of genetically-restricted proviral DNA in the female genital tract after heterosexual transmission of HIV-1. Aids 21:153-162.

Chomont N, El-Far M, Ancuta P, Trautmann L, Procopio F A, Yassine-Diab B, Boucher G, Boulassel M R, Ghattas G, Brenchley JM, Schacker TW, Hill BJ, Douek DC, Routy JP, Haddad EK, Sekaly RP. 2009. HIV reservoir size and persistence are driven by T cell survival and homeostatic proliferation. Nat Med 15:893-900.

Chun TW, Nickle DC, Justement JS, Meyers JH, Roby G, Hallahan CW, Kottilil S, Moir S, Mican JM, Mullins JI, Ward DJ, Kovacs JA, Mannon PJ, Fauci AS. 2008. Persistence of HIV in gut-associated lymphoid tissue despite long-term antiretroviral therapy. J Infect Dis 197:714-720. 
Clayton F, Snow G, Reka S, Kotler DP. 1997. Selective depletion of rectal lamina propria rather than lymphoid aggregate CD4 lymphocytes in HIV infection. Clin Exp Immunol 107:288-292.

Delwart EL, Mullins JI, Gupta P, Learn GH, Jr., Holodniy M, Katzenstein D, Walker BD, Singh MK. 1998. Human immunodeficiency virus type 1 populations in blood and semen. J Virol 72:617-623.

Delwart EL, Shpaer EG, Louwagie J, McCutchan FE, Grez M, Rubsamen-Waigmann H, Mullins JI. 1993. Genetic relationships determined by a DNA heteroduplex mobility assay: analysis of HIV-1 env genes. Science 262:1257-1261.

Felsenstein J. 2001. PHYLIP, Phylogeny Inference Package, version 3.6 (alpha). Seattle: Department of Genetics, University of Washington.

Guindon S, Gascuel O. 2003. A simple, fast, and accurate algorithm to estimate large phylogenies by maximum likelihood. Syst Biol 52:696-704.

Jordan MR, Kearney M, Palmer S, Shao W, Maldarelli F, Coakley EP, Chappey C, Wanke C, Coffin JM. 2010. Comparison of standard PCR/cloning to single genome sequencing for analysis of HIV-1 populations. J Virol Methods 168:114-120.

Korber BT, Kunstman KJ, Patterson BK, Furtado M, McEvilly MM, Levy R, Wolinsky SM. 1994. Genetic differences between blood- and brain-derived viral sequences from human immunodeficiency virus type 1-infected patients: evidence of conserved elements in the V3 region of the envelope protein of brain-derived sequences. J Virol 68:7467-7481.

Mowat AM, Viney JL. 1997. The anatomical basis of intestinal immunity. Immunol Rev 156:145-166.

Poles MA, Boscardin WJ, Elliott J, Taing P, Fuerst MM, McGowan I, Brown S, Anton PA. 2006. Lack of Decay of HIV-1 in Gut-Associated Lymphoid Tissue Reservoirs in Maximally Suppressed Individuals. J Acquir Immune Defic Syndr 43:65-68.

Poles MA, Elliott J, Vingerhoets J, Michiels L, Scholliers A, Bloor S, Larder B, Hertogs K, Anton PA. 2001. Despite high concordance, distinct mutational and phenotypic drug resistance profiles in human immunodeficiency virus type 1 RNA are observed in gastrointestinal mucosal biopsy specimens and peripheral blood mononuclear cells compared with plasma. J Infect Dis 183:143-148.

Thompson JD, Gibson TJ, Plewniak F, Jeanmougin F, Higgins DG. 1997. The CLUSTAL_X windows interface: flexible strategies for multiple sequence alignment aided by quality analysis tools. Nucleic Acids Res 25:4876-4882.

van der Hoek L, Goudsmit J, Maas J, Sol CJ. 1998. Human immunodeficiency virus type 1 in faeces and serum: evidence against independently evolving subpopulations. J Gen Virol 79:2455-2459.

van Marle G, Church DL, Nunweiler KD, Cannon K, Wainberg MA, Gill MJ. 2010. Higher levels of Zidovudine resistant HIV in the colon compared to blood and other gastrointestinal compartments in HIV infection. Retrovirology 7:74.

van Marle G, Gill MJ, Kolodka D, McManus L, Grant T, Church DL. 2007. Compartmentalization of the gut viral reservoir in HIV-1 infected patients. Retrovirology 4:87.

van't Wout AB, Ran LJ, Kuiken CL, Kootstra NA, Pals ST, Schuitemaker H. 1998. Analysis of the temporal relationship between human immunodeficiency virus type 1 quasispecies in sequential blood samples and various organs obtained at autopsy. $\mathrm{J}$ Virol 72:488-496.

Veazey RS, DeMaria M, Chalifoux LV, Shvetz DE, Pauley DR, Knight HL, Rosenzweig M, Johnson RP, Desrosiers RC, Lackner AA. 1998. Gastrointestinal tract as a major site of CD4+ T cell depletion and viral replication in SIV infection. Science 280:427-431. 
359 Veazey RS, Lackner AA. 2005. HIV swiftly guts the immune system. Nat Med 11:469-470. 360 Wang TH, Donaldson YK, Brettle RP, Bell JE, Simmonds P. 2001. Identification of shared 361 populations of human immunodeficiency virus type 1 infecting microglia and tissue 362 363 364 365 366 367 368 369 370 macrophages outside the central nervous system. J Virol 75:11686-11699.

Wong JK, Ignacio CC, Torriani F, Havlir D, Fitch NJ, Richman DD. 1997. In vivo compartmentalization of human immunodeficiency virus: evidence from the examination of pol sequences from autopsy tissues. J Virol 71:2059-2071.

Yukl SX, Gianella S, Sinclair E, Epling L, Li Q, Duan L, Choi AX, Girling V, Ho T, Li P, Fujimoto K, Lampiris H, Hare CX, Pandori M, Haase AX, Nthard HX, Fischer M, Shergill AX, McQuaid K, Havlir DX, Wong JX. 2010. Differences in HIV Burden and Immune Activation within the Gut of HIV-Positive Patients Receiving Suppressive Antiretroviral Therapy. J Infect Dis 202:1553-61.

Zhu T, Wang N, Carr A, Nam DS, Moor-Jankowski R, Cooper DA, Ho DD. 1996. Genetic characterization of human immunodeficiency virus type 1 in blood and genital secretions: evidence for viral compartmentalization and selection during sexual transmission. J Virol 70:3098-3107. 